\title{
The Effect of Indonesian and Hokkien Mobile Learning Application Models
}

\author{
Al-Khowarizmi' ${ }^{1}$ Fauzi $^{2}$, Indah Purnama Sari ${ }^{3}$, Ajulio Padly Sembiring ${ }^{4}$ \\ 1,3Department of InformationTechnology, Universitas Muhammadiyah Sumatera Utara, Indonesia \\ 2Department of Accounting, Akademik YPK Medan, Indonesia \\ ${ }^{4}$ Department of Computer Engineering and informatics, Politeknik Negeri Medan, Indonesia
}

\begin{abstract}
Tiongkok is a country with a large population and is in several states. In addition, Tiongkok has a variety of languages. Hokkien is the worldwide language of China and is widely known to many people. This is evidenced by the many China Town markets. In Indonesia there has been a lot of Hokkien language guidance. In almost every elementary school in the city, adding Hokkien language lessons is a must for elementary school students. Even starting from the playgroup has also been taught Hokkien. But still there are children who do not understand because of the different ways of writing by reading Hokkien. In this research, the writer makes an android-based hokkien language learning media which can be utilized by users with mobile technology, designed learning media adapted to the curriculum in elementary schools with 5 subject matter. From the results of testing designed learning media can help make it easier for students to better understand hokkien language.
\end{abstract}

Keyword : Hokkien, Learning Media, Mobile Application.

\section{Corresponding Author:}

Al-Khowarizmi,

Department of Information Technology,

Universitas Muhammadiyah Sumatera Utara,

Jalan Kapten Muktar Basri No 3 Medan 20238, Indonesia.

Email: alkhowarizmi@umsu.ac.id

\section{INTRODUCTION}

Education is a strategic institution whose existence is strongly influenced by almost all scientific disciplines, community development, philosophy and culture, religious values and others. Education is a institution whose main task is to prepare humanity to be ready and able to face its future [1][2]. For this reason, education is needed that provides life skills, namely providing skills and expertise with high competence [3]. With the possession of life skills students are expected to survive in an atmosphere that will always change and develop [4].

Reference [5] explains that there are several things that need to be elaborated on the concept of education contained in the Act. First, education is a conscious effort that is planned, this means the educational process is not a process that is carried out carelessly and fortunately, but a process that aims so that everything done by teachers and students is directed towards the achievement of goals. Second, the planned process is directed towards realizing an atmosphere of learning and learning process, this means that education must not rule out the learning process. Education is not merely trying to achieve learning outcomes, but how to obtain results or learning processes that occur in children. Third, the atmosphere of learning and learning is directed so that students can develop their potential, this means the educational process must be student-oriented [6]. Education must strive to develop the potential of students [7]. Thus, children must be seen as organisms that are developing and have potential [8]. Until the end of the education process is the ability of children to have spiritual spiritual strength, self-control, personality, intelligence, noble character and the skills needed by themselves, society, nation and state [9]. This means that the educational process leads to the formation of attitudes, the development of intelligence or intellectual, and the development of children's skills in accordance with the needs [10].

Mastering various languages is the highest value of skills [11]. The most widely spread language in the world is Chinese [12]. Chinese has various languages, one of which is Hokkien. This is evidenced by the many China Town markets in almost every city [13]. So based on these explanations, the authors are interested in creating a learning media based on Indonesian mobile applications and Hokkien language that is equipped with an online-based examination process. 


\section{RESEARCH METHOD}

The research method is a way to get back the solution to all problems. The research methodology was carried out in several stages, namely:

1. Data Collection

a) Literature Study, this writing begins with a literature study that is collecting reference materials both from books, articles, journals, papers, and internet sites about the process of conducting the exam, as well as the programming language for the application creation, and several other references.

b) Experimental, namely the design and implementation of systems to make a clear picture of the problems faced by making application programs using the programming language

2. Development the program

The development of this application uses the Waterfall methodology, with the following stages:

a) System Engineering: this stage is the activity of collecting data to support the development of the system and determine in what direction this application will be built.

b) System Analysis: gathering complete requirements then analyzed and defined needs that must be met by the application to be built. This stage must be done in full to be able to produce a complete design.

c) System Design: interface design from the results of the needs analysis that has been completed is collected in full.

d) Coding System: the results of system design are translated into codes using a predetermined programming language. Applications that are built directly are tested both on a unit basis.

e) System Testing: the uniting of the program units is then tested as a whole.

f) System Maintenance: operate applications in their environment and carry out maintenance, such as adjustments or changes due to adaptation to the actual situation.

g) Feedback: is a response from the system user that can be used to find out the extent to which the application being built is received by the user.

\section{RESULTS AND DISCUSSION}

In this paper, it will be explained about the stages carried out in the design of Android-based Hokkien learning media. The stages include the analysis process in the form of application specification analysis, architecture of the system designed, system design consisting of the design of use case diagrams, database design, menu structure design and application interface design both for admin and for Mobilebased users.

\section{A. System Design}

The design that will be presented by the author is the design by describing the system architecture, use case diagrams, menu design to interface design that can be described. In this application will discuss about reading letters, numbers and words that are used daily and writing in the Han script. The application starts with a learning menu option starting from lesson 1 - lesson 4, common words and dictionaries. In each lesson there are ways of writing and quiz. For everyday word menus have similarities in running the application that will appear a list of common words and how to pronounce in hokkien. In this application there is also a dictionary form. For the dictionary form there is a textbox and a button. If students want to find Chinese from a word, hanzi and pinyin will appear from the word. For the quiz menu, the Han script will appear, and students will follow the writing method on the screen in the order they appear.

The design concept in making this application is a combination of visual or display concepts, color concepts and typographic concepts or writing concepts. With these three concepts, learning applications will be more interesting and favored by users.

1. Visual Concepts

For visual concepts or appearance, the authors choose to use simple designs, but still interesting to look at. This is because the target of this application, namely elementary school children.

2. Colors Concepts

The colors that dominate this application are red, yellow, gray, brown. The colors were chosen because they match the colors of Chinese culture and the colors that kids like. 
3. Typographic Concepts

The typeface used in the learning application is a typeface that is simple and easy for the user to read. In the selection of letters there are criteria that have been adjusted including:

a. The typeface must be able to represent the character as a manifestation of the material presented.

b. Fonts must have a high level of readability.

The typography used is:

1. Segoe

This font was chosen because the character of this font is simple and very clearly read by children.

2. Comic Sans MS

This font was chosen because the character of this font is cheerful suitable for children and is very popular with children and is often used in children's magazines.

B. Use Case Diagram

Use case diagrams illustrate the activities carried out on a system with events that occur when someone or something interacts with the system. The following use case diagram of an Android-based hokkien learning media can be seen in Figure 1.

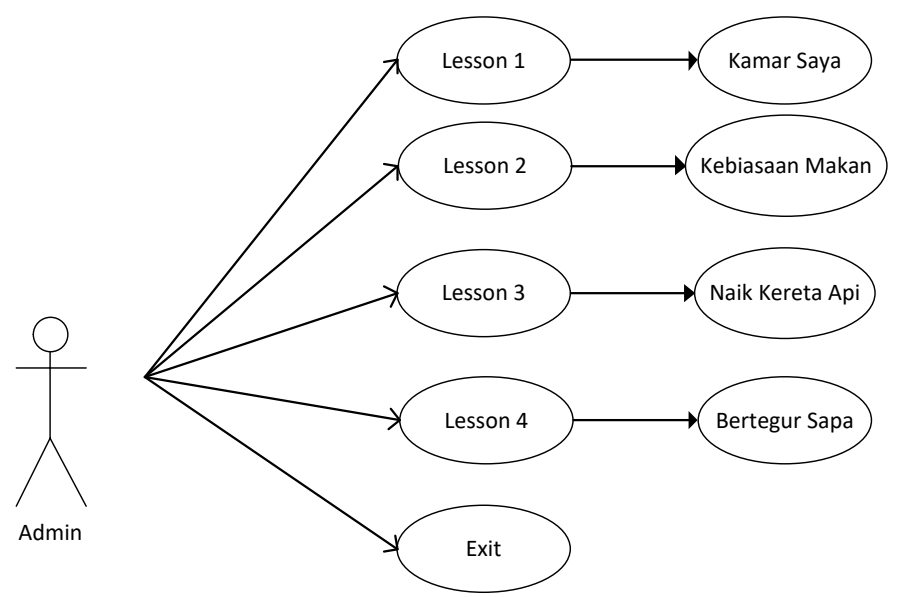

Figure 1. Use Case Diagrams of Mobile Device Users

The explanation of the use case diagram above in table 1 :

\begin{tabular}{ccc} 
Table 1 Explanation of Use Case Admin Chart \\
Actor & $\begin{array}{c}\text { Use Case } \\
\text { Name }\end{array}$ & $\begin{array}{c}\text { Use Case } \\
\text { Description }\end{array}$ \\
User & $\begin{array}{c}\text { Look } \\
\text { Lesson 1 }\end{array}$ & $\begin{array}{c}\text { Use this case to } \\
\text { function to see my } \\
\text { room material }\end{array}$ \\
\hline User & $\begin{array}{c}\text { Look } \\
\text { Lesson 2 }\end{array}$ & $\begin{array}{c}\text { Use this case functions } \\
\text { to see the material of } \\
\text { eating habits }\end{array}$ \\
\hline User & $\begin{array}{c}\text { Look } \\
\text { Lesson 3 }\end{array}$ & $\begin{array}{c}\text { Use case is used to } \\
\text { view material on the } \\
\text { train }\end{array}$ \\
\hline User & Look & $\begin{array}{c}\text { Use case is used to } \\
\text { view greeting material }\end{array}$ \\
\hline exson 4 & $\begin{array}{c}\text { Use this case functions } \\
\text { to exit the media }\end{array}$
\end{tabular}


a. Menu Structure Design

To simplify the design of the application, it is necessary to design a menu structure that will be built. The design of this menu structure will show a general description of the application. The design of this menu structure will be divided into 2 parts, namely the user menu structure and admin menu structure.

The design of the user menu structure will show a general description of the application that will be built specifically for the user / client side. This menu structure is intended for application users namely Mobile device users.

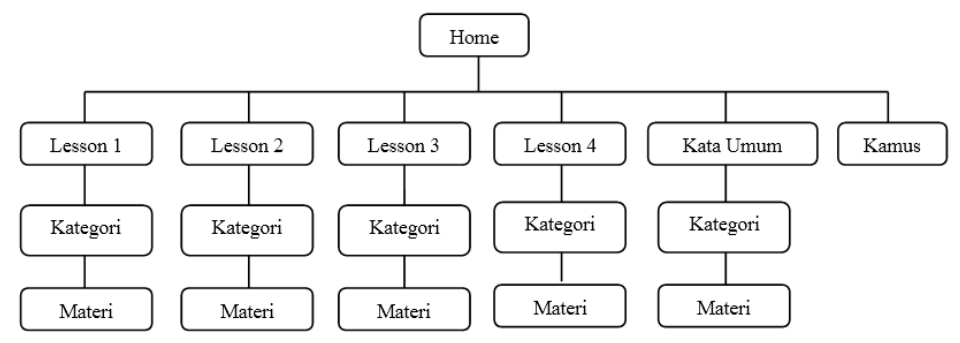

Figure 2. User Menu Structure Design

b. Program Display

In the program view application pages that are made are inseparable from the interface design that has been previously designed. The following pages display from both the mobile (client) and application admin side.

These pages are pages provided for android users which in this case act as clients who request data from the server.

1. Splash Screen

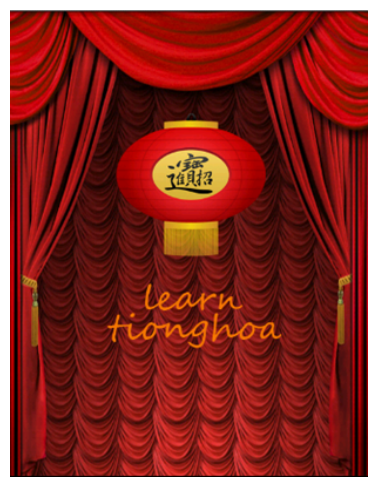

Figure 3. Splash Screen

2. Main Menu

This page is the main menu of the application that provides the menus or features provided. The menus / features are Lesson 1, Lesson 2, Lesson 2, Lesson 4, Common words, dictionaries and Exit material.

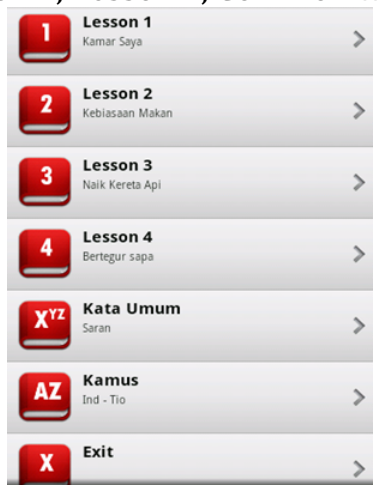

Figure 4. Main Menu 
This page is the main page contained in the application. There are 4 (four) lessons, common words and dictionaries that have links to each page. The four lessons are My Room, Eating Habits, Taking the Train and Greeting.

3. Category

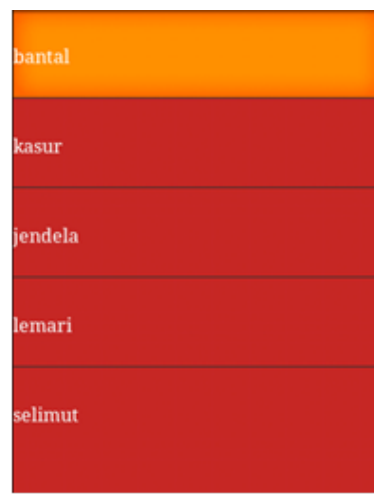

Figure 5. Category

This page displays a list of categories of Lessons related to the topics discussed. The list is a menu to proceed to each link to find out material from the selected category.

4. Material

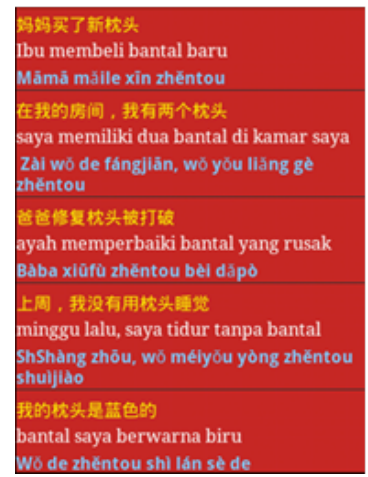

Figure 6. Material

This page displays a list of material from the Lesson category related to the topic discussed. The list displays the Han characters, pinyin and Indonesian related to the selected category.

5. General Word

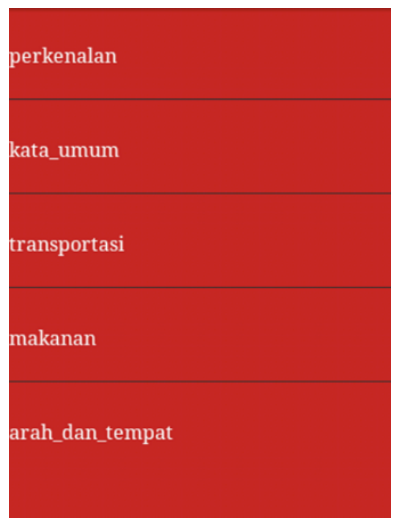

Figure 7. General Word 
This page displays a list of categories of common words. The list is a menu to proceed to each link to find out material from the selected category.

6. Sugession

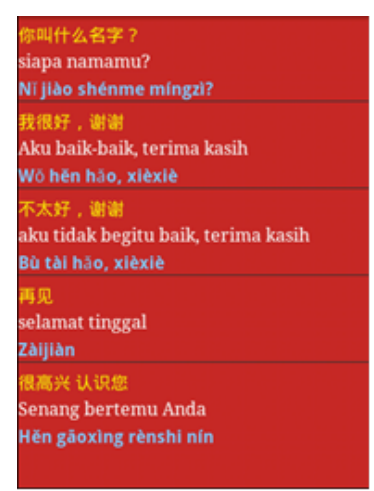

Figure 8. Sugession

This page displays a list of material from the General Words category related to the topic discussed. The list displays the Han characters, pinyin and Indonesian related to the selected category.

7. Searching

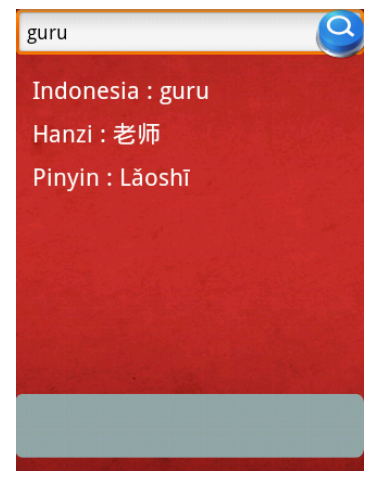

Figure 9. Kamus

This page is a dictionary page. This page is used to search for words in hokkien. There is an editview and a button. This page is only for searching words from Indonesian into Hokkien.

\section{CONCLUSION}

The conclusion that can be drawn from making mobile-based hokkien language learning applications is that this application runs as expected and is able to assist the teacher's task in providing material in accordance with the curriculum. This application is used and used to facilitate children in learning Hokkien.

\section{REFERENCES}

[1] Saputra, R. (2018). Pembaruan Pendidikan Pesantren Dalam Meningkatkan Sumber Daya Manusia (Perspektif Kha Wahid Hasyim) (Doctoral Dissertation, Uin Raden Intan Lampung).

[2] Rosmaini, E., Kusumasari, T. F., Lubis, M., \& Lubis, A. R. (2018). Study to the current protection of personal data in the educational sector in Indonesia. In Journal of Physics: Conference Series (Vol. 978, No. 1, p. 012037). IOP Publishing.

[3] Kartilawati, K., \& Warohmah, M. (2014). Profesionalisme Guru Pendidikan Agama Islam Di Era Teknologi Informasi Dan Komunikasi. Ta'dib: Journal Of Islamic Education (Jurnal Pendidikan Islam), 19(01), 143-168.

[4] Megawati, A. (2013). Penerapan Prinsip Pembelajaran Orang Dewasa (Andragogi) Pada Program Life Skill Di Sanggar Kegiatan Belajar Kabupaten Pati (Doctoral Dissertation, Universitas Negeri Semarang).

[5] Bahri, S. (2017). Pengembangan Kurikulum Dasar Dan Tujuannya. Jurnal Ilmiah Islam Futura, 11(1), 15-34.

[6] Taufiq, A. (2014). Pendidikan Anak Di Sd.

JCoSITTE, Vol. 1, No. 1, March 2020 : $1-7$ 
[7] Dianti, P. (2014). Integrasi Pendidikan Karakter Dalam Pembelajaran Pendidikan Kewarganegaraan Untuk Mengembangkan Karakter Siswa. Jurnal Pendidikan Ilmu Sosial, 23(1).

[8] Syarbini, A. (2014). Model Pendidikan Karakter Dalam Keluarga. Elex Media Komputindo.

[9] Raharjo, S. B. (2010). Pendidikan Karakter Sebagai Upaya Menciptakan Akhlak Mulia. Jurnal Pendidikan Dan Kebudayaan, 16(3), 229-238.

[10] Kartikasari, G. (2016). Pengaruh Media Pembelajaran Berbasis Multimedia Terhadap Motivasi Dan Hasil Belajar Materi Sistem Pencernaan Manusia: Studi Eksperimen Pada Siswa Kelas V Mi Miftahul Huda Pandantoyo. Dinamika Penelitian: Media Komunikasi Penelitian Sosial Keagamaan, 16(1), 59-77.

[11] Qalbi, U. N., Mantasiah, R., Jufri, J., \& Yusri, Y. (2017). Efektivitas Model Pembelajaran Kooperatif Tipe Teams Games Tournaments Dalam Keterampilan Menulis Bahasa Jerman Siswa Kelas Xii Ipa Sma Negeri 1 Bontonompo Kabupaten Gowa. Indonesian Journal Of Educational Studies, 20(1).

[12] Aziz, A. L. (2014). Penguatan Identitas Bahasa Indonesia Sebagai Lambang Identitas Nasional Dan Bahasa Persatuan Jelang Penerapan Masyarakat Ekonomi Asean (Mea) 2015. Jurnal Studi Sosial, 6(1), 14-20.

[13] Yaslana, W. (2019). Gardens By The Bay Sebagai Daya Tarik Wisata Unggulan Singapura.

\section{BIOGRAPHIES OF AUTHORS}

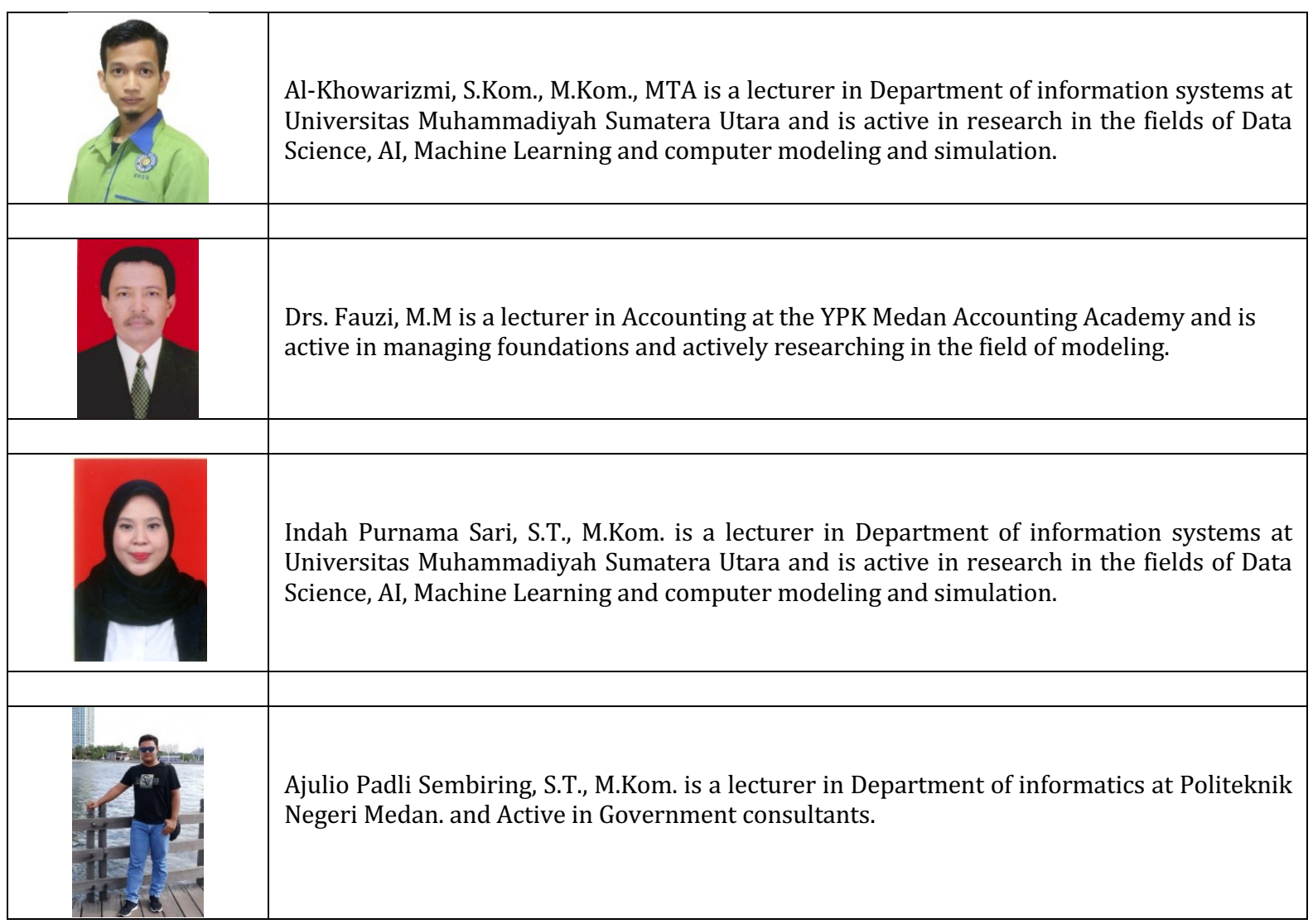

